\title{
Coral sand from hydraulic reclamation for the remediation of acid sulfate soil
}

\author{
Jiachen Zeng ${ }^{1, \mathrm{a}}$, Yuchi Hao ${ }^{1, \mathrm{~b}}$, Wenbo Sun ${ }^{1 *}$, De Wei ${ }^{2, \mathrm{c}}$, Runli Tao ${ }^{1, \mathrm{~d}}$, Baolin Shi ${ }^{3, \mathrm{e}}$, Jianfei Zheng ${ }^{3, \mathrm{f}}$, Zhen \\ Zhang ${ }^{3, g}$ \\ ${ }^{1}$ CCCC National Engineering Research Center of Dredging Technology and Equipment Co., Ltd, 1088 \\ Yangshupu Road, Shanghai, 200082, PR China \\ ${ }^{2}$ CCCC Shanghai Dreging Co., Ltd, 13, Zhongshan East 1st Road, Shanghai, 200002, PR China \\ ${ }^{3}$ CHEC Dredging Co., Ltd, 92 Yuanshen Road, Shanghai, 200120, PR China
}

\begin{abstract}
For the first time, Coral sand, as the main geotechnical material in reclamation, has the characteristics of loose and porous structure, relatively small volume and mass, easy to break and high compression, and high calcium carbonate, which may be a natural material to control acid release of acid soil. In this paper, by studying the neutralization effect of coral sand under different sand ratio, particle size and adding methods, the optimal dosage and particle size of coral sand and the adding sequence were determined under typical acid soil conditions; The neutralization performance of different neutralizing materials was compared through internal structure characterization, and the structural advantages of coral sand were explored. The results show that the specific surface area of coral sand was $1.2361 \mathrm{~m}^{2} \mathrm{~g}^{-1}$, second only to calcite and shell powder. The particles were evenly distributed and can fully react with sulfuric acid to produce $\mathrm{CaSO} 4$ precipitation. When the addition of coral sand was $9 \%(\mathrm{Ca}: \mathrm{S}=18: 5)$, the PASS can be neutralized to $\mathrm{pH}>6.5$. The PASS neutralization ability of coral sand was related to particle size. The overall trend was that the smaller the particle size, the stronger the neutralization ability. The best effect was at $0.15 \mathrm{~mm}$, when the particle size exceeded $0.27 \mathrm{~mm}$, the neutralization ability began to decline.
\end{abstract}

\section{Introduction}

Potential acid sulphate soil (PASS) was often associated with reclamation projects in subtropical and tropical areas. Acid sulfate soil are naturally formed soils or sediments that are produced under waterlogged and poorly drained conditions. is developed in the parent material rich in reducing sulfide, mainly pyrite $\left(\mathrm{FeS}_{2}\right)$, which is an extremely bad soil containing reducing sulfur. The potential acid sulphate soil dredged ashore was exposed to the atmosphere ${ }^{[1]}$. After the oxidation of pyrite in the soil, a large number of strong acid substances such as sulfuric acid and sulfite are produced, which not only polluted the ecological environment, but also corroded the building materials. The sulfides can move to the surface water and into subsurface water and cause loss of nutrients in the soil and destroy the soil structure ${ }^{[2]}$.
In the reclamation project, natural coral sand was mixed with dredged soil and then dredged to the shore ${ }^{[3]}$. Coral sand is the main geotechnical material in the reclamation project, which mainly composed of $\mathrm{CaCO}_{3}$, $\mathrm{MgCO}_{3}$ and other insoluble carbonates ${ }^{[4]}$. The interior of coral sand has the characteristics of loose structure, small volume mass, easy to break and high compression ${ }^{[5]}$, which is expected to be a natural improvement material for potential acidic soil in land reclamation. Some studies ${ }^{[2]}$ showed that $\mathrm{CaCO}_{3}$ and polyacrylamide (PAM) as the soil ameliorants were applied to neutralize ASS and improve the permeability of the soil.

The main crystal forms of coral sand are aragonite, calcite and magnesium calcite. The results showed that calcium oxalate precipitates were formed by the reaction of high concentration oxalic acid and coral sand, which were bonded to the surface of coral sand ${ }^{[6]}$. Magnesium calcite, aragonite and calcite are preferentially dissolved

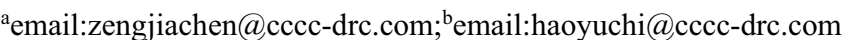

*email:sunwenbo@cccc-drc.com; 'email:weide@cccc-sdc.com demail:taorunli@cccc-drc.com; eemail:shibaolin@hotmail.com femail:269625047@qq.com; 'email:402283450@qq.com

*Corresponding author: sunwenbo@cccc-drc.com
} 
in the dissolution process ${ }^{[7]}$. The particle size of coral sand affects the acid neutralization performance and the dissolution of $\mathrm{Ca}^{2+}$ and $\mathrm{Mg}^{2+}$. Akio Yosano et al. ${ }^{[8]}$ Studied the neutralization ability of coral sand, and found that the neutralization curve of coral sand with particle size less than $0.5 \mathrm{~mm}$ was similar to that of $\mathrm{CaCO}_{3}$ for fertilizer, and the neutralization ability is roughly the same, and decreases with the increase of particle size. Some studies ${ }^{[9]}$ have shown that coral calcareous sands with different particle sizes have potential effects on soil physical and chemical properties and enzyme activities. The application effect of calcareous sand with particle size of 0.075-0.25 $\mathrm{mm}$ was equivalent to that of $\mathrm{CaCO}_{3}$, while the application effect of calcareous sand with particle size $<0.075 \mathrm{~mm}$ was better than that of $\mathrm{CaCO}_{3}$. Li et al found ${ }^{[10]}$ that dissolution efficiency of $\mathrm{Ca}^{2+}, \mathrm{Mg}^{2+}$ in small coral sand is high and can be dissolved by low molecular organic acids. However, at present, there are few reports on the treatment of PASS by coral sand in reclamation project area. It is of great significance to study the self

neutralization law of coral sand to acid soil for soil treatment and resource utilization of coral sand in reclamation project in harbor area.

\section{Materials and methods}

\subsection{Materials Preparation}

Acid sulfate soils (ASS) were collected from mangrove area in Sanya City, Hainan Province, China. Table 1 lists the basic properties of ASS. After hydrogen oxidation, the $\mathrm{pH}$ value was decreased to 2.5. The $\mathrm{pH}$ of sulfidecontaining soil was 6.33 , which was decreased to 3.22 after hydrogen oxidation. Usually, soil with high organic substance and anaerobic condition (PASS) contain $>5 \%$ total sulfur ${ }^{[11]}$. Nevertheless, as the sample used in this study has been dried, the data has, therefore, yielded a lower value of total sulfur $(<5 \%)$ with a disproportionate percentage of organic carbon $(>3 \%)^{[12]}$.

Table 1. Basic properties of acid sulphate soil

\begin{tabular}{|l|l|}
\hline Parameter & Value \\
\hline pH (1:2 water soil mass ratio) & 6.33 \\
\hline pH-OX & 3.22 \\
\hline EC (ds/m, 1:1water soil mass ratio) & 2.35 \\
\hline Organic carbon $(\%)$ & 0.36 \\
\hline Total nitrogen $(\%)$ & 0.037 \\
\hline Cation exchange capacity $(\mathrm{mg} / \mathrm{kg})$ & 126 \\
\hline Available phosphorus $(\mathrm{ppm})$ & 2.8 \\
\hline Available zinc (ppm) & 0.75 \\
\hline Exchangeable calcium $(\mathrm{mg} / \mathrm{kg})$ & 8.1 \\
\hline Substitutive magnesium $(\mathrm{mg} / \mathrm{kg})$ & 6.2 \\
\hline Exchangeable potassium $(\mathrm{mg} / \mathrm{kg})$ & 7.5 \\
\hline Alternative sodium $(\mathrm{mg} / \mathrm{kg})$ & 4.9 \\
\hline Fe (ppm) & 70.0 \\
\hline Al (ppm) & 67.3 \\
\hline K (ppm) & 54.7 \\
\hline C (ppm) & 57.9 \\
\hline Na (ppm) & 12.4 \\
\hline Ca (ppm) & 9.1 \\
\hline S (ppm) & 8.5 \\
\hline Mg (ppm) & 5.2 \\
\hline
\end{tabular}

These values were similar to those of field identification. In addition, a pyrite sample (PS) was supplied by a polymetallic sulfide mine in Xiangshan District, Guilin City, Yunnan Province.

The coral sand samples were taken from a dredger fill reef in the South China Sea. Table 2 lists the basic properties of coral sand. The main element was $\mathrm{Ca}$, accounting for $95.854 \%$. In addition, trace elements such as $\mathrm{Sr}, \mathrm{Si}, \mathrm{S}, \mathrm{Mg}$ are detected. The study ${ }^{[13]}$ shows that the higher the calcium content, the stronger the acid-base neutralization ability. The samples were light gray in color, rough in surface, low in strength and brittle in quality. Before the test, the particle size distribution of the samples was not uniform, the main particle size distribution was $12-30 \mu \mathrm{m}$, there were coarse particles larger than $1.5 \mathrm{~mm}$, but the content was less than $2 \%$. In the dosage inquiry test, in order to avoid the influence of particle size effect on the test results of acid soil, the coarse particles in the 
sample were removed, and the adjusted particle gradation is shown in Fig. 1.

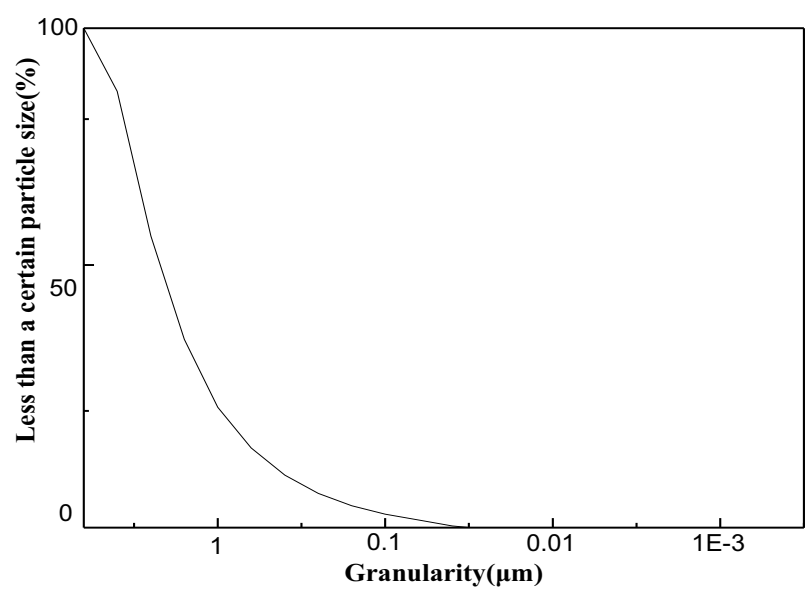

Fig.1 Grading curve of coral sand

Table 2 Basic components of coral sand

\begin{tabular}{|c|c|}
\hline Element & Content \\
\hline $\mathrm{Ca}$ & $95.854 \%$ \\
\hline $\mathrm{Sr}$ & $2.236 \%$ \\
\hline $\mathrm{Si}$ & $0.537 \%$ \\
\hline $\mathrm{S}$ & $0.352 \%$ \\
\hline $\mathrm{Mg}$ & $0.371 \%$ \\
\hline $\mathrm{Fe}$ & $0.268 \%$ \\
\hline $\mathrm{K}$ & $0.096 \%$ \\
\hline $\mathrm{Cu}$ & $0.046 \%$ \\
\hline $\mathrm{Br}$ & $0.039 \%$ \\
\hline $\mathrm{Zn}$ & $0.021 \%$ \\
\hline
\end{tabular}

Dolomite, shell, calcite, montmorillonite, hydrated lime was supplied by a quarry. They were milled to 0.15 $\mathrm{mm}$ before being used and denoted as $\mathrm{DM}_{\mathrm{P}}, \mathrm{SH}_{\mathrm{P}}, \mathrm{CA}_{\mathrm{P}}$, $\mathrm{ML}_{\mathrm{P}}$ and $\mathrm{HL}_{\mathrm{P}}$. Coral sand was ground to $0.15 \mathrm{~mm}$, denoted as $\mathrm{CS}_{\mathrm{P}}$

\subsection{Characterizations}

The solid of $\mathrm{CS}_{\mathrm{P}}$ was analyzed by X-ray diffraction and electron microscope analyzer. Inductively coupled plasma atomic emission spectrometry (ICP) was used to determine the contents of $\mathrm{Ca}, \mathrm{Mg}$ and $\mathrm{Fe}$ in coral sand solution after digestion.X-ray diffraction (XRD) was recorded on a $\mathrm{D} / \mathrm{max}-2500 \mathrm{~V}+/ \mathrm{PC}$ diffractometer (Rigaku Industrial Co., Ltd.), which was equipped with an monochromatized $\mathrm{Cu} \mathrm{K}$ radiation. The scanning speed was $8 \%$ min.and the scanning range was $5-80^{\circ}$. Micromorphology was characterized with scanning electron microscopy (HTREM, JEOL JEM2010).

\subsection{Dynamic analysis of coral sand self neutralization}

$3 \mathrm{~g}\left(\right.$ acid soil \& $\left.\mathrm{CA}_{\mathrm{P}}\right),\left(\mathrm{PS} \& \mathrm{CA}_{\mathrm{P}}\right)$ and $\left(\mathrm{CA}_{\mathrm{P}} \& 2 \mathrm{ml} 1 \mathrm{~mol}\right.$ / $\mathrm{L}$ sulfuric acid) were mixed with each other in $20 \mathrm{ml}$ of deionized for $30 \mathrm{~min}$. Then, $\mathrm{H}_{2} \mathrm{O}_{2}(\mathrm{pH}=7)$ was added to the mixture, which was then stirred for $30 \mathrm{~min}$. Afterward, the mixture was centrifugated, dried at $105^{\circ} \mathrm{C}$, and milled to 100 mesh. The sample was recorded as $\mathrm{S} 1 \sim \mathrm{S} 3$.

$\mathrm{X}$-ray diffractometer was used to characterize $\mathrm{S} 1$ S3.The pore size data of $\mathrm{CA}_{\mathrm{P}}, \mathrm{SH}_{\mathrm{P}}, \mathrm{DM}_{\mathrm{P}}, \mathrm{ML}_{\mathrm{P}}, \mathrm{CA}_{\mathrm{P}}$ and $\mathrm{HL}_{\mathrm{P}}$ were obtained by BET test.

\subsection{Neutralization ability}

The neutralization test of PASS can be divided into two situations: the first is synchronous oxidation neutralization, and the relationship between oxidation rate and neutralization rate is explored according to the change of $\mathrm{pH}$ value in each period; the second is oxidation first and then neutralization, which aims to explore the neutralization rate of various neutralizing agents.

In order to investigate the influence of $\mathrm{CS}_{\mathrm{P}}$ dosage on $\mathrm{pH}$, experiments were designed as follows: $\mathrm{X} g$ of $\mathrm{CS}_{\mathrm{P}}$ was mixed with $5 \mathrm{~g}$ of ASS and $10 \mathrm{~mL}$ of $\mathrm{H}_{2} \mathrm{O}_{2}(\mathrm{pH}=7)$. The weight ratio of $\mathrm{Ca}$ in $\mathrm{CS}_{\mathrm{P}}$ and $\mathrm{S}$ content in ASS was $\mathrm{X}: 1(\mathrm{X}=0.4,0.8,1.2,1.6,2.0,2.4,2.8,3.2$ and 3.6); the weight ratio of $\mathrm{H}_{2} \mathrm{O}_{2}$ and $\mathrm{S}$ content was $200: 1$. The reaction time was $45 \mathrm{~min}$. Each experiment was denoted as PX. The $\mathrm{pH}$ value of soil suspension was tested every five minutes ${ }^{[14]}$.

Table 3 lists the specific experimental design. 
Table 3 PASS test method

\begin{tabular}{|c|c|c|c|c|c|c|c|}
\hline & Type & $\begin{array}{c}\text { Particle } \\
\text { size }(\mathrm{mm})\end{array}$ & $\begin{array}{c}M(n): \\
\text { S }\end{array}$ & Soil & $\mathrm{H}_{2} \mathrm{O}_{2}: \mathrm{S}$ & Time & Methods \\
\hline \multirow{7}{*}{1} & \multirow{7}{*}{ Coral sand } & 0.075 & $2: 1$ & $5 \mathrm{~g}$ & $200: 1$ & $45 \mathrm{~min}$ & \multirow{11}{*}{$\begin{array}{l}\text { Simultaneous } \\
\text { oxidation } \\
\text { neutralization }\end{array}$} \\
\hline & & 0.15 & $2: 1$ & $5 \mathrm{~g}$ & $200: 1$ & $45 \mathrm{~min}$ & \\
\hline & & 0.27 & $2: 1$ & $5 \mathrm{~g}$ & $200: 1$ & $45 \mathrm{~min}$ & \\
\hline & & 0.5 & $2: 1$ & $5 \mathrm{~g}$ & $200: 1$ & $45 \mathrm{~min}$ & \\
\hline & & $0.8-1.2$ & $2: 1$ & $5 \mathrm{~g}$ & $200: 1$ & $45 \mathrm{~min}$ & \\
\hline & & 2 & $2: 1$ & $5 \mathrm{~g}$ & $200: 1$ & $45 \mathrm{~min}$ & \\
\hline & & $3-4$ & $2: 1$ & $5 \mathrm{~g}$ & $200: 1$ & $45 \mathrm{~min}$ & \\
\hline 2 & Montmorillonite & 0.15 & $2: 1$ & $5 \mathrm{~g}$ & $200: 1$ & $45 \mathrm{~min}$ & \\
\hline 3 & Shell powder & 0.15 & $2: 1$ & $5 \mathrm{~g}$ & $200: 1$ & $45 \mathrm{~min}$ & \\
\hline 4 & $\begin{array}{l}\text { Hydrated lime } \\
\text { powder }\end{array}$ & 0.15 & $2: 1$ & $5 \mathrm{~g}$ & $200: 1$ & $45 \mathrm{~min}$ & \\
\hline 5 & Dolomite & 0.15 & $2: 1$ & $5 \mathrm{~g}$ & $200: 1$ & $45 \mathrm{~min}$ & \\
\hline 6 & Calcite & 0.15 & $2: 1$ & $5 \mathrm{~g}$ & $200: 1$ & $45 \mathrm{~min}$ & \\
\hline 7 & Coral sand & 0.15 & $2: 1$ & $5 \mathrm{~g}$ & $200: 1$ & $45 \mathrm{~min}$ & \multirow{6}{*}{$\begin{array}{l}\text { Oxidation before } \\
\text { neutralization }\end{array}$} \\
\hline 8 & Hydrated lime & 0.15 & $2: 1$ & $5 \mathrm{~g}$ & $200: 1$ & $45 \mathrm{~min}$ & \\
\hline 9 & Calcite & 0.15 & $2: 1$ & $5 \mathrm{~g}$ & 200:1 & $45 \mathrm{~min}$ & \\
\hline 10 & Shell powder & 0.15 & $2: 1$ & $5 \mathrm{~g}$ & $200: 1$ & $45 \mathrm{~min}$ & \\
\hline 11 & Dolomite & 0.15 & $2: 1$ & $5 \mathrm{~g}$ & $200: 1$ & $45 \mathrm{~min}$ & \\
\hline 12 & Montmorillonite & 0.15 & $2: 1$ & $5 g$ & $200: 1$ & $45 \mathrm{~min}$ & \\
\hline
\end{tabular}

Note: $\mathrm{Mn}: \mathrm{S}$ is the ratio of neutralizing materials to sulfur content in acid soil; $\mathrm{H}_{2} \mathrm{O}_{2}: \mathrm{S}$ is the ratio of hydrogen peroxide to sulfur in acid soil.

\section{Results and discussion}

\subsection{Neutralization performance}

According to the standard for disposal of acid soil in actual dredging project, the PASS after neutralization material treatment must meet $\mathrm{pH}_{\mathrm{F}} \geq 6.5, \mathrm{pH}_{\mathrm{FOX}} \geq 6.5$ ( $\mathrm{pHF}$ is the in-situ $\mathrm{pH}$ value of the dredged material to be treated, $\mathrm{pH}_{\mathrm{FOX}}$ is the $\mathrm{pH}$ value oxidized by hydrogen peroxide) to meet the land use standard. In order to explore the best proportion of coral sand and PASS for complete neutralization $(\mathrm{pH} \geq 6.5$ after complete oxidation), researchers used different proportions of coral sand to neutralize acid sulfate soil.

Fig. 2 shows the change of $\mathrm{pH}$ along with time when the ratio of $\mathrm{CS}_{\mathrm{P}}$ was increased from $0.4: 1$ to 3.6:1. During 0-5 min, the $\mathrm{pH}$ value was decreased significantly, which indicated that pyrite in the acid soil was oxidized to produce sulfuric acid. After 5 minutes, the decreasing trend of $\mathrm{pH}$ became slow. At this time, sulfuric acid produced by oxidation is neutralized by $\mathrm{CS}_{\mathrm{P}}, \mathrm{H}^{+}$reacted with $\mathrm{CaCO}_{3}$ in $\mathrm{CS}_{\mathrm{P}}$. As a result, the $\mathrm{pH}$ was decreased from 7.0 to 5.9. Then, P1.6, P2, P2.4, P2.8, P3.2, P3.6 curve showed a slow upward trend, indicating that $\mathrm{CaCO}_{3}$ in $\mathrm{CS}_{\mathrm{P}}$ play as the role of neutralizing acid and fixing sulfate. Finally, the $\mathrm{pH}$ value was stable around 6.3 (5.8 6.5), which indicated that most of the sulfuric acid is neutralized.

Fig. 2 also shows that the order of neutralization effect of each proportion followed the order of P0.4< $0.8<$ $\mathrm{P} 1.2<\mathrm{P} 1.6<\mathrm{P} 2<\mathrm{P} 2.4<\mathrm{P} 2.8<\mathrm{P} 3.2<\mathrm{P} 3.6$. When the ratio of $\mathrm{Ca}$ and $\mathrm{S}$ in acid soil was $0.4: 1$, the $\mathrm{pH}$ of oxidation products reached stability after 30 minutes, and the $\mathrm{pH}$ value was stable at 5.0, which was higher than that of undisturbed soil. In other words, when the $\mathrm{Ca}$ : $\mathrm{S}$ reached 18:5, the $\mathrm{pH}$ value of PASS was adjusted to 6.32, indicating the best dosage of $\mathrm{CS}_{\mathrm{P}}$, which met the requirements of acid soil disposal. 


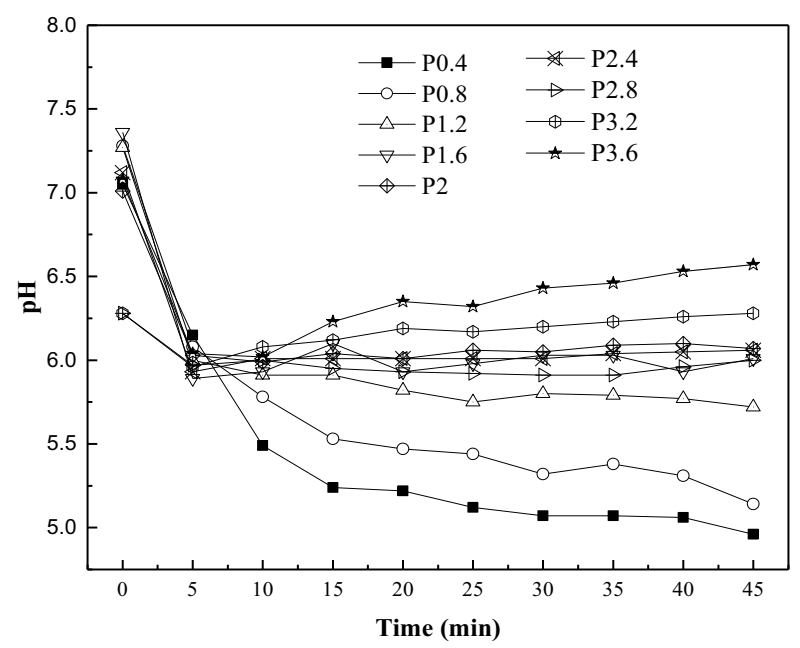

Fig. 2 Effect of coral sand addition ratio on $\mathrm{pH}$ after complete oxidation

In order to compare the advantages and disadvantages of coral sand with other neutralizing materials, it is necessary to explore the change of neutralization rate when neutralizing agent was added after oxidation of acid soil.

Fig. 3 shows the order of neutralization effect of each material followed the order of $\mathrm{ML}_{\mathrm{P}}<\mathrm{DM}_{\mathrm{P}}<\mathrm{CS}_{\mathrm{P}}<\mathrm{CA}_{\mathrm{P}}=$ $\mathrm{SH}_{\mathrm{P}}<\mathrm{HL}_{\mathrm{P}}$. The neutralization rate of $\mathrm{CS}_{\mathrm{P}}$ was slower than that of $\mathrm{HL}_{\mathrm{P}}, \mathrm{CA}_{\mathrm{P}}, \mathrm{SH}_{\mathrm{P}}, \mathrm{DM}_{\mathrm{P}}$ and $\mathrm{ML}_{\mathrm{P}}$, reached stability at 50 minutes. At this time, the $\mathrm{pH}$ value was second only to $\mathrm{SH}_{\mathrm{P}}$ and $\mathrm{CA}_{\mathrm{P}}$, and less than HLP. Because of its strong alkalinity, $\mathrm{HL}_{\mathrm{P}}$ was easy to cause soil salinization, lime was expected to improve the $\mathrm{pH}$ level of soil, which was at extreme acidity with a value of $\mathrm{t}<3.5^{[12]}$, the requirements in using modified lime on acid-sulfate lands or pyritic, which has been an aquaculture regime, are found to be inappropriate and unreliable ${ }^{[15]}$. Although the neutralization rate of $\mathrm{CS}_{\mathrm{P}}$ was relatively slow, it has the characteristics of high alkali content and high porosity. It has an outstanding effect on the prevention and control of PASS.

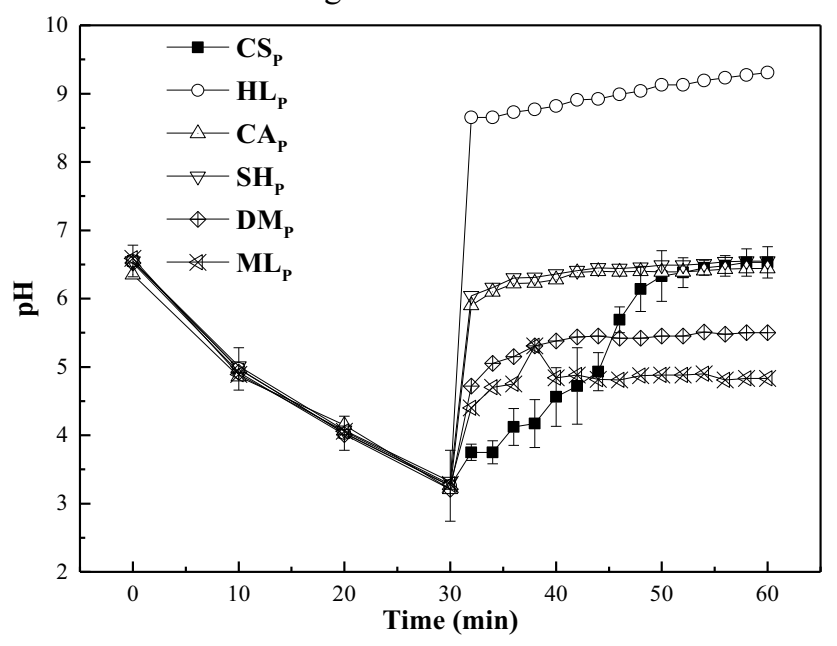

Fig. 3 Neutralization rate test of different neutralization materials

\subsection{Particle size effect}

Fig.4 shows that the overall trend of $\mathrm{pH}$ decreased with the increase of particle size of coral sand when coral sand and PASS were mixed synchronously. When the particle size of coral sand was $0.15 \mathrm{~mm}$, the best neutralization effect was obtained, and the $\mathrm{pH}$ value was finally stabilized around 5.95. When the particle size was reduced to $0.075 \mathrm{~mm}$, the decrease rate of $\mathrm{pH}$ was faster than that of $0.15 \mathrm{~mm}$ coral sand, but the $\mathrm{pH}$ at the end point is slightly lower than the former.The neutralization effect of
$0.15 \mathrm{~mm}$ coral sand is better than that of $0.075 \mathrm{~mm}$ coral sand. Generally speaking, the relationship between particle size and neutralization capacity was not simply that the smaller the particle size, the stronger the neutralization ability. For PASS, it may be related to whether the particle size of neutralizing materials matches the soil particles. When the particle size $0.5 \mathrm{~mm}$ was $0.5 \mathrm{~mm}$, the $\mathrm{pH}$ value decreased significantly, and the final $\mathrm{pH}$ value was about 5.35 . When the particle size changed to $3-4 \mathrm{~mm}$, the end point $\mathrm{pH}$ value was 4.27 , which increased by 1 unit compared with the original soil after complete oxidation. 


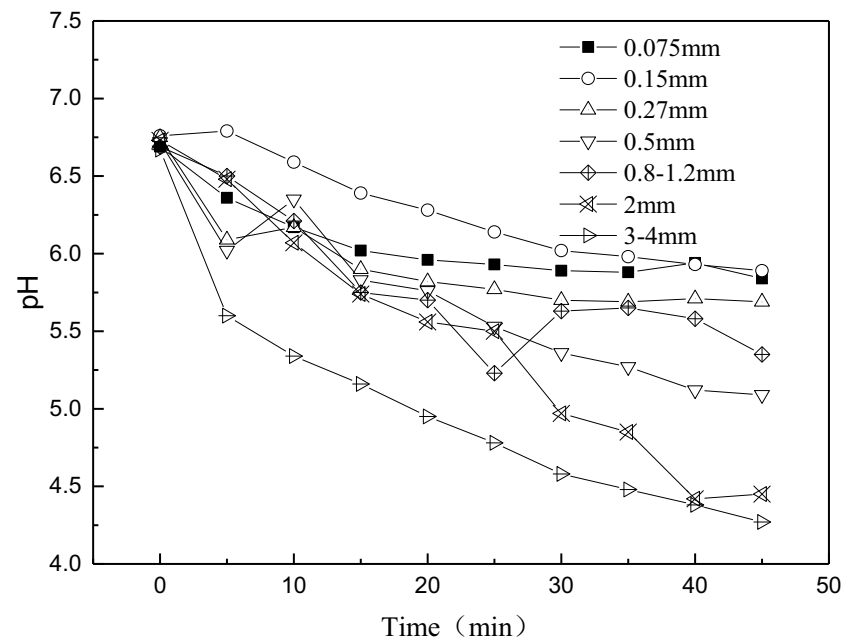

Fig. 4 Test of coral sand particle size (simultaneous oxidation neutralization)

Fig. 5 shows that the neutralization capacity and neutralization rate of coral sand decrease with the increase of particle size. The results show that the neutralizing acid content of coral sands with particle sizes of $0.075 \mathrm{~mm}$, $0.15 \mathrm{~mm}$ and $0.27 \mathrm{~mm}$ were similar, but the neutralization rate was different, and the $\mathrm{pH}$ value at the end point was around 6.5 . The neutralization rate of $0.075 \mathrm{~mm}$ and $0.15 \mathrm{~mm}$ coral sand was significantly better than that of $0.27 \mathrm{~mm}$ coral sand. When the particle size was larger than
$0.27 \mathrm{~mm}$, the neutralization rate decreased significantly, and the terminal $\mathrm{pH}$ decreased to about 5.1. The neutralization rate at $0.5 \mathrm{~mm}$ was slightly lower than that at $0.27 \mathrm{~mm}$, and the final $\mathrm{pH}$ was 6.03 . Although the increase of particle size has a great impact on the neutralization effect of coral sand, the coral sand larger than $0.5 \mathrm{~mm}$ still has neutralization ability. When the particle size was $3-4 \mathrm{~mm}$, compared with the undisturbed soil, the $\mathrm{pH}$ was still increased by 1.5 units.

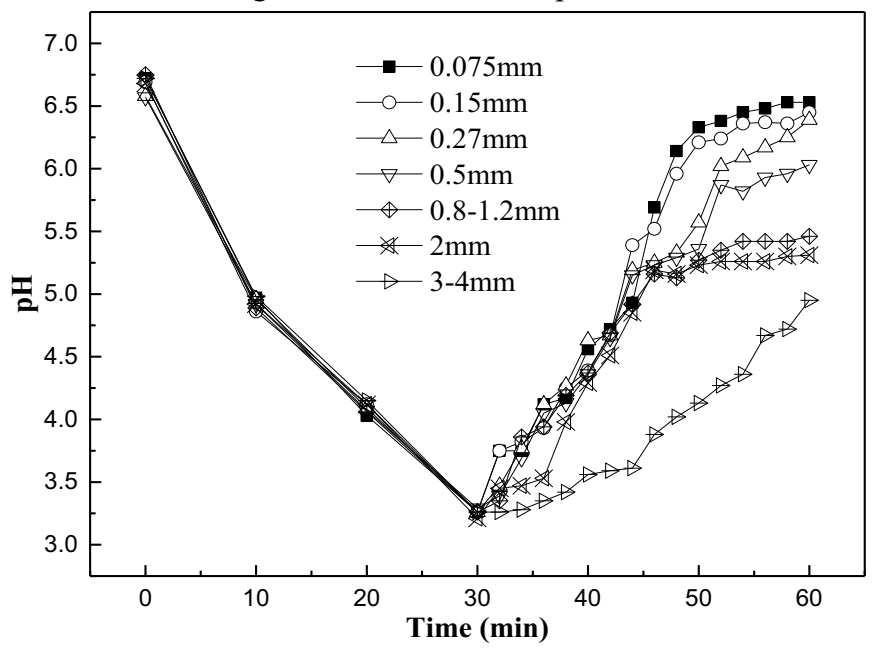

Fig. 5 Test of coral sand particle size (preferential oxidation)

\subsection{Properties and reaction mechanism}

Fig. 6 shows the X-ray diffraction pattern. The characteristic peaks of 3.4085 (111), 3.2851 (021), 2.7089 (012), 2.4912 (102), 2.3791 (112), 1.9805 (221), 1.8849 (202), 1.8179 (132) and 1.7459 (113) were the characteristic spectral lines of aragonite, which match the powder diffraction card (PDF •\# 71-1663). After screening and comparison, the characteristic peak 2.9957 (104) was determined to be the characteristic peak of magnesium calcite. In addition, a small number of mixed peaks show that there was a small amount of calcite in the coral sand, which indicated that the contents of calcite, magnesium calcite and aragonite in coral sand are $10.2 \%$, $21.5 \%$ and $68.3 \%$, respectively. 


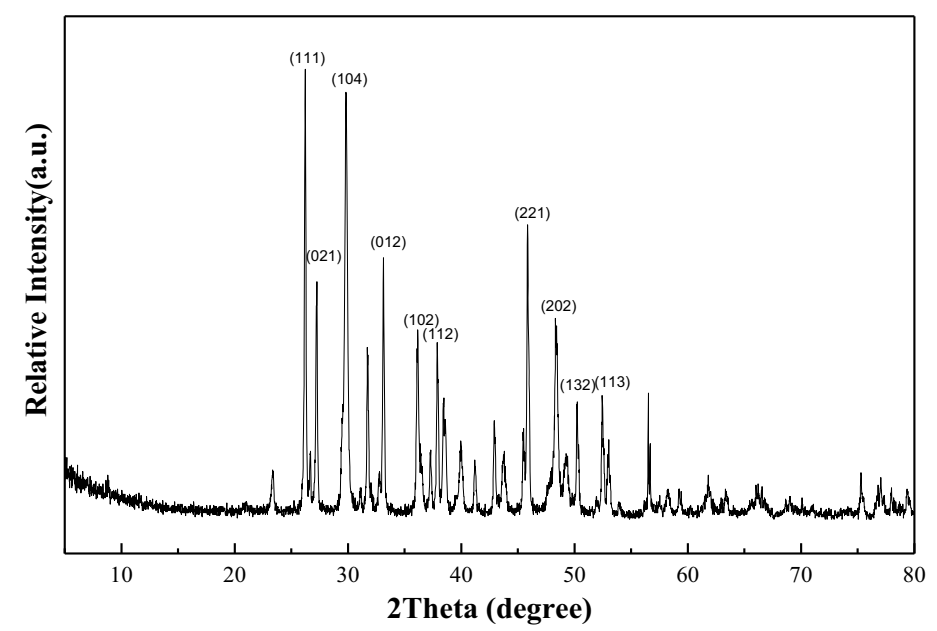

Fig. 6 XRD of Coral sand

In the SEM image of coral sand (Fig. 7), it can be clearly observed that the structural units of coral sand are long strip-shaped cubic deposits, with high angle and irregular shape of particles, many rod-shaped and flaky

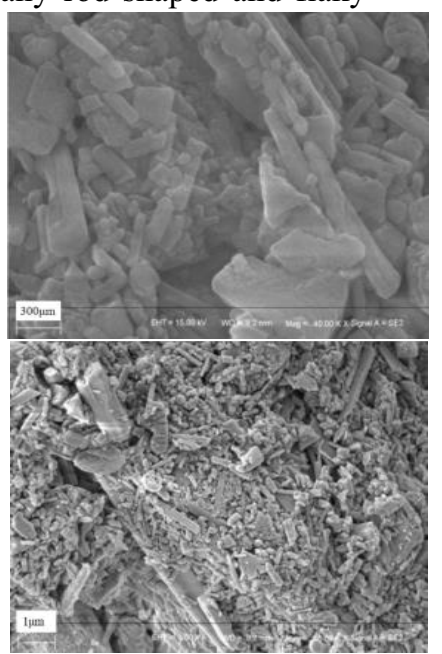

Fig. 7 SEM

Fig. 8 shows the main crystal image composition of coral sand was $\mathrm{CaCO}_{3}$ (PDF·\#41-1475) and calcium silicate (PDF * \# 27-0088), so it has strong neutralization performance. The main crystal images of $\mathrm{S} 1$ were $\mathrm{CaCO}_{3}$, $\mathrm{CaAl}_{2} \mathrm{Si}_{2} \mathrm{O}_{8} \cdot 4 \mathrm{H}_{2} \mathrm{O}$ (PDF $\cdot \#$ 20-0452) ${ }^{[16]}$ and $\mathrm{SiO}_{2}(\mathrm{PDF} \cdot \#$ 46-1045). $\mathrm{CaAl}_{2} \mathrm{Si}_{2} \mathrm{O}_{8} \cdot 4 \mathrm{H}_{2} \mathrm{O}$ is the main component of anorthite. Batch adsorption studies ${ }^{[17]}$ show that it is an effective adsorbent to remove $\mathrm{CO}^{2+}$ and $\mathrm{Sr}^{2+}$ from acidic aqueous medium. The final products of $\mathrm{S} 3$ are mainly $\mathrm{CaSO}_{4}(\mathrm{PDF} \cdot \# 23-0128)$ and $\mathrm{CaCO}_{3}$. Therefore, it can be inferred that the reaction process of coralline sand and pure sulfuric acid is the reaction of $\mathrm{CaCO}_{3}$ and sulfuric acid, and the $\mathrm{CaSO}_{4}$ produced successfully fixed $\mathrm{SO}_{4}{ }^{2-}$ in coralline sand. The crystal image of $\mathrm{S} 2$ product was similar to that of $\mathrm{S} 3$ product, which is $\mathrm{CaSO}_{4}$ and $\mathrm{CaCO}_{3}$. PS was completely oxidized to produce $\mathrm{H}_{2} \mathrm{SO}_{4}$, which reactd with $\mathrm{CaCO}_{3}$ to form $\mathrm{CaSO}_{4}$ slightly soluble in water. Hence, to some extent, $\mathrm{CaCO}_{3}$ in coral sand can fix sulfur element in PS. A study shows ${ }^{[18]}$ that as a common neutralizer of ASS, $\mathrm{CaCO}_{3}$ can not only neutralize the sulfuric acid produced by oxidation, but also inhibit the oxidation rate of ASS, there was minimal sulfide particles, and many internal pores. The structure has a large specific surface area, which is conducive to the full neutralization reaction with sulfuric acid.

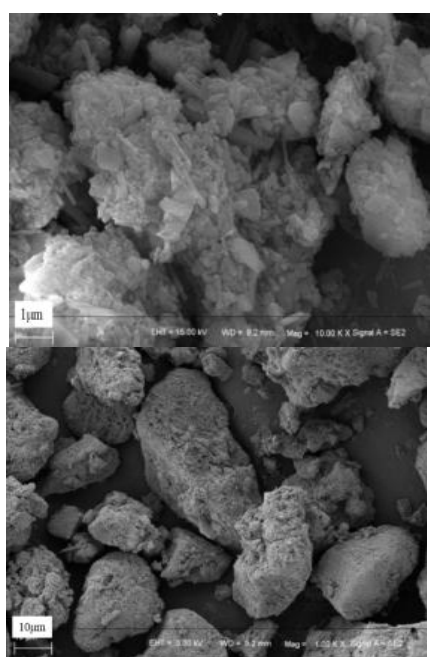

Coral sand

oxidation and no acidification after the addition of excess $\mathrm{CaCO}_{3}$ over the 180 days of incubation. 


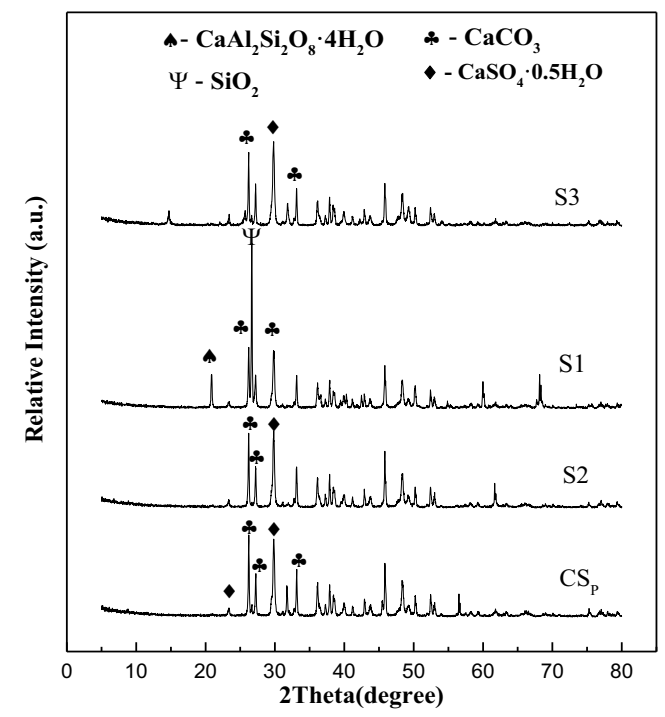

Fig. 8 XRD of reaction products of $\mathrm{CS}_{\mathrm{P}}$ and $\mathrm{S} 1-\mathrm{S} 3$

\subsection{Structural advantages}

Fig. 9 compared the structural characteristics of several neutralizing materials. Montmorillonite shows IV type isotherm $^{[19]}$ and $\mathrm{H} 3$ type hysteresis loop ${ }^{[20]}$, which indicated that it has complex mesoporous structure and irregular pore structure. Shell powder, coral sand, calcite and dolomite showed I-type isotherm ${ }^{[21]}$, and there was no hysteresis loop, which indicated that they had the characteristics of microporous adsorbent ${ }^{[22]}$, and the saturated adsorption value was equal to the filling volume of micropores. In addition, the order of BET surface area (Table 4): $\operatorname{DM}_{\mathrm{P}}\left(0.16287 \mathrm{~m}^{2} \mathrm{~g}^{-1}\right)<\mathrm{CS}_{\mathrm{P}}\left(1.2361 \mathrm{~m}^{2} \mathrm{~g}^{-1}\right)<$ $\mathrm{CA}_{\mathrm{P}}\left(2.5932 \mathrm{~m}^{2} \mathrm{~g}^{-1}\right)<\mathrm{SH}_{\mathrm{P}}\left(3.297 \mathrm{~m}^{2} \mathrm{~g}^{-1}\right)<\operatorname{ML}_{\mathrm{P}}\left(69.448 \mathrm{~m}^{2}\right.$ $\left.\mathrm{g}^{-1}\right)$. The bet order of each material was different from that of the pore size. The order of pore size was $\mathrm{ML}_{\mathrm{P}}<\mathrm{CA}_{\mathrm{P}}<$ $\mathrm{DM}_{\mathrm{P}}<\mathrm{SH}_{\mathrm{P}}<\mathrm{CS}_{\mathrm{P}}$, which was different from the law of neutralization rate, but partly similar. Although montmorillonite has high specific surface area, its pore size was small and its neutralization rate was slow . $\mathrm{DM}_{\mathrm{P}}$ and $C A_{P}$ have similar pore size, but the specific surface area of $\mathrm{CA}_{P}$ was much higher than $\mathrm{DM}_{\mathrm{P}}$, and its neutralization ability was better than dolomite.

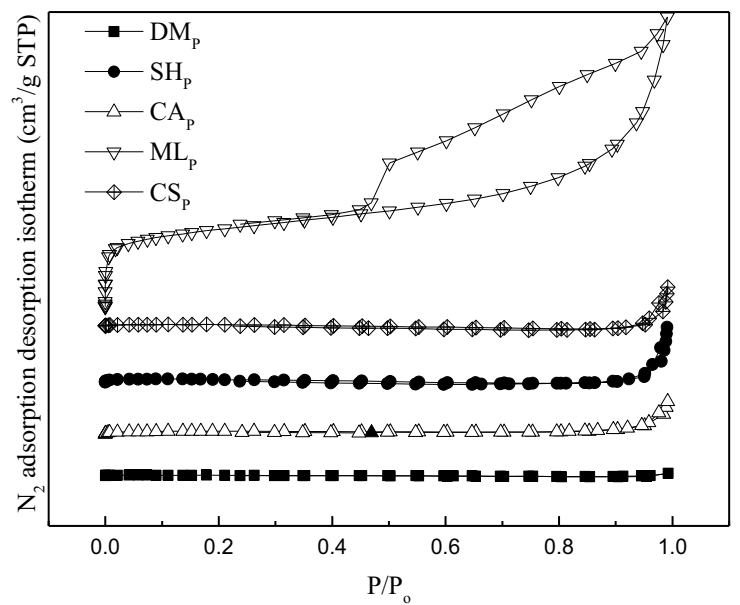

Fig. 9 Adsorption isotherms of several neutralizing materials

Table 4. Specific surface areas of several neutralizing materials

\begin{tabular}{|c|c|c|c|}
\hline & BET $\left(\mathrm{m}^{2} \mathrm{~g}^{-1}\right)$ & $\begin{array}{c}\text { Total pore volume } \\
(\mathrm{p} / \mathrm{p} 0=0.99)\end{array}$ & Average aperture (nm) \\
\hline $\mathrm{DM}_{\mathrm{P}}$ & 0.16287 & 0.00077437 & 19.018 \\
\hline $\mathrm{SH}_{\mathrm{P}}$ & 3.297 & 0.020098 & 24.383 \\
\hline $\mathrm{CA}_{\mathrm{P}}$ & 2.5932 & 0.011594 & 17.883 \\
\hline $\mathrm{ML}_{\mathrm{P}}$ & 69.448 & 0.1121 & 6.4577 \\
\hline $\mathrm{CS}_{\mathrm{P}}$ & 1.2361 & 0.012523 & 40.524 \\
\hline
\end{tabular}


Therefore, the neutralization ability of materials was affected by specific surface area and pore size. $\mathrm{CS}_{\mathrm{P}}$ has a small specific area, but its average pore size was the highest among several neutralizing materials, which was $40.524 \mathrm{~nm}$. Its large pore size can well react with acid and adsorb sulfate ion in the process of acid damage control of PASS, which can be used as a good PASS amendment.

\section{Conclusion}

In this work, coral sand was used to treat the PASS in the harbor area as a common calcium containing material in the reclamation of land. In general, the smaller the particle size was, the stronger the neutralization ability was. The best neutralization effect was at $0.15 \mathrm{~mm}$. When the particle size exceeded $0.27 \mathrm{~mm}$, coral sand still has neutralization effect on the PASS. When the median particle size was $0.5 \mathrm{~mm}$, the neutralization ability was $20 \%$ lower than that of coral sand below $0.27 \mathrm{~mm}$. When the particle size increased to $3-4 \mathrm{~mm}$, the neutralization ability was $50 \%$. From the mixing mode, the final $\mathrm{pH}$ value of oxidation before neutralization was higher than that of synchronous mixing, which indicated that oxidation before neutralization can make sulfuric acid react with neutralizing materials better. After characterization, it was found that the coral sand has a large specific surface area $\left(1.2361 \mathrm{~m}^{2} \mathrm{~g}^{-1}\right)$, second only to calcite and shell powder. The particles were evenly distributed and can fully react with sulfuric acid to produce $\mathrm{CaSO}_{4}$ precipitation. When Ca: $\mathrm{S}=18: 5$, the PASS can be neutralized to $\mathrm{pH}>6.5$. The neutralization rate of coral sand was lower than that of calcite and shell powder, but it can provide the same alkali. As the inevitable product of land reclamation, coral sand is much easier to obtain than calcite and shell powder, so it is an ideal neutralization material for PASS.

\section{Acknowledgements}

This project was financially supported by overseas business department of CCCC Shanghai Dreging Co., Ltd. We appreciate Instrumental Analysis \& Research Center of Shanghai University for the help of sample characterizations.

\section{Reference}

[1] Nyberg M, E., Osterholm O., Nystrand M, I. (2012) Impact of acid sulfate soils on the geochemistry of rivers in south-western Finland [J]. Environmental Earth Sciences, 66(1): 157-68.

[2] Song Y-S. (2020) Unsaturated Characteristics of Acid Sulfate Soils before and after Neutralization Treatment [J]. Ksce Journal of Civil Engineering, 24(12): 3640-3649.

[3] Pancrazi I, Ahmed H, Cerrano C. (2020) Synergic effect of global thermal anomalies and local dredging activities on coral reefs of the Maldives [J]. Marine Pollution Bulletin, 160(30):2637-2648.

[4] Gao R., Ye J-H. (2019) Experimental investigation on the dynamic characteristics of calcareous sand from the reclaimed coral reef islands in the South China Sea [J]. Rock and Soil Mechanics, 40(10): 3897-906.

[5] Ye J., Cao M., Li G. (2019) Preliminary study on the creep characteristics of calcareous sand from reclaimed coral reef islands in South China Sea [J]. Chinese Journal of Rock Mechanics and Engineering, 38(6): 1242-1251.

[6] Watabe Y, Sassa S, Kaneko T. (2017) Mechanical characteristics of undisturbed coral gravel soils: The intergranular void ratio as a common governing parameter [J]. Soils and Foundations, 57(5): 760-775.

[7] Li Y., Li P., Pan J. (2020) Study on the Corrosion of Coral Sand by Oxalic Acid [J]. Journal of Ecology and Rural Environment, 36(7): 905-913.

[8] Yosano A., Takashi I., Hideo I. (1989) Application of coral sand in agriculture $[\mathrm{J}]$. Soil science exhibition (Chinese), 1989(01): 27-39.

[9] Zhao M., Jin F., Sun Z. (2014) Effects of Pyrolysis Condition on Basic Group of Biochar and Amelioration of Acid Soil [J]. Journal of Soil and Water Conservation, 28(4): 299.

[10] LiP. (2019) Study on the effect of low molecular weight organic acids on weathering and dissolution of coral sand [D]; Lanzhou Jiaotong University.

[11] Boyd C E. (2003) Bottom soil and water quality management in shrimp ponds [J]. Appl Aquac, 13(12): 23.

[12] Fitrani M., Wudtisin I., Kaewnern M.(2020) The impacts of the single-use of different lime materials on the pond bottom soil with acid sulfate content [J]. Aquaculture, 2020, 527(12):356-367.

[13] Boyd C E., Daniels H V. (1994) Liming and Fertilization of Brackishwater Shrimp Ponds [J]. Journal of Applied Aquaculture, 1994, 2(3-4): 221234.

[14] Thunjai T, Boyd C E, Duke K. (2001) Pond soil pH measurement. [J]. World Aquac1, 32(12):135-167.

[15] Boyd C E. (2017) Use of agricultural limestone and lime in aquaculture [J]. CAB Rev, 2017, 12(15):102118.

[16] Zhang Y L, Liu X M, Xu Y T, Et Al. (2019) Preparation and characterization of cement treated road base material utilizing electrolytic manganese residue $[\mathrm{J}]$. Journal of Cleaner Production, 232(9): 80-92.

[17] Coleman N J, Brassington D S, Raza A, Et Al. (2006) Sorption of $\mathrm{Co}^{2+}$ and $\mathrm{Sr}^{2+}$ by waste-derived $11 \mathrm{~A}$ tobermorite [J]. Waste Management, 26(3): 260-267.

[18] Ward N J., Sullivan L A., Bush R T. (2002) Sulfide oxidation and acidification of acid sulfate soil materials treated with $\mathrm{CaCO}_{3}$ and seawaterneutralised bauxite refinery residue $[\mathrm{J}]$. Australian Journal of Soil Research, 40(6): 1057-1067.

[19] Wilk L J., Ciechanowska A., Kociolek-Balawejder E. (2020) Adsorptive-Oxidative Removal of Sulfides from Water by MnO2-Loaded Carboxylic Cation Exchangers [J]. Materials, 13(22): 1526-1537.

[20] Pawar R R., Lalhmunsiama., Ingole P G, et al. (2020) Use of activated bentonite-alginate composite beads for efficient removal of toxic $\mathrm{Cu}^{2+}$ and $\mathrm{Pb}^{2+}$ ions from 
aquatic environment [J]. International Journal of Biological Macromolecules, 164(3):145-154.

[21] Zuo L., Wang Y P., Guo W.,(2014) Methane Adsorption on Shale: Insights from Experiments and a Simplified Local Density Model [J]. Adsorption Science \& Technology, 32(7): 535-556.

[22] Park H Y., Lee C H., Cho D W. (2020) Synthesis of porous carbon derived from poly (vinylidenefluoride) and its adsorption characteristics for $\mathrm{CO}_{2}$ and $\mathrm{CH}_{4}[\mathrm{~J}]$. Microporous and Mesoporous Materials, 299(12):1347-1356. 